\title{
Taxonomic significance of the seed characters of certain species of tribe Asclepiadeae in Egypt
}

\author{
Samia Heneidak* and Abdel-Rahman E. Hassan**
}

*Biological \& geological Department, Faculty of Education in Suez, Suez
Canal University, Egypt, E-mail: sheneidak2000@ yahoo.com
**Agricultural Botany Department, Faculty of Agriculture, Ismailia, Suez
Canal University, Egypt

Heneidak, S. \& Hassan, A.E. 2005. Taxonomic significance of the seed characters of certain species of tribe Asclepiadeae in Egypt Taeckholmia 25: 91-109.

\begin{abstract}
Seed external morphology and coat anatomy of ten species of tribe Asclepiadeae (Asclepiadoideae-Apocynaceae) in Egypt are investigated using Light Microscope (LM) and Scanning Electron Microscope (SEM). Seed features studied include variations in shape, colour, texture, hilar details, surface scan characteristics and seed coat anatomy. Anatomically, the testa has been found to be of greatest value in determining taxonomic relationships. Some seed characters were found to be very distinct at the generic level, such as the presence of two rows of the palisade-like cells of the seed wing (one upper and one lower) which could be considered as taxonomic marker for the two Pergularia species. In addition, the presence of mounds on the upper concave side of the seed coat is recorded only in two Asclepias species and Solenostemma arghel; with large, tubular, lignified, pitted cells in two Asclepias species, and small, rectangular, radially elongated in Solenostemma arghel.
\end{abstract}

Key words: Apocynaceae, Asclepiadeae, Asclepiadoideae, seed anatomy, seed coat sculpture.

\section{Introduction}

The Apocynaceae and Asclepiadaceae (including Periplocaceae) are more closely related to each other than to the other families in Gentianales. Recently Endress \& Bruyns (2000) classified the Apocynaceae sensu lato into five subfamilies; Rauvolfioideae, Apocynoideae, Periplocoideae, 
Secamonoideae and Asclepiadoideae. The old Asclepiadaceae (Periplocoideae, Secamonoideae and Asclepiadoideae) consists of 250-320 genera comprising 1700-2900 species (Heywood, 1978; Mabberley, 1997). They have many representatives in East and South Africa, Latin America and South East Asia with many representatives in South America. Many authors; Täckholm (1956 \& 1974) El-Hadidi \& Fayed (1994/1995); Boulos (1995 \& 2000) recognized 9 genera including 11 species in tribe Asclepiadeae from Egypt. Seven monotypic genera include Calotropis, Cynanchum, Glossonema, Oxystelma, Pentatropis, Pleurostelma and Solenostemma; whereas Gomphocarpus and Pergularia with two species.

The fruit is a pair of follicles containing numerous winged seeds crowened by a tuft of silky hairs (coma) that is important domestically for the "down" of low quality obtained (Lawrence, 1978). The seeds show narrow endosperm surrounding a white straight embryo, and contain 20$50 \%$ oils (Mahran et al., 1967a).

The application of SEM in the study of the seed coat have become wide spread and many studies on seed morphology and anatomy of the sympetalous plants in relation to their taxonomy have been carried out by Singh et al. (1972) (Compositae); Sampathkumar \& Ayyangar (1978), Govil (1980), and Hamed \& Mourad (1994) (Convolvulaceae); Al-Nowaihi \& Mourad (1999) and Shaheen (2002) (Solanaceae). The latter authors have also referred to the importance of the variations in seed coat sculpture in the identification and classification of some solanaceous taxa.

Seed coats may be complex multilayered tissues, or simply enlarged ovule wall (Rudall 2000). They generally include a hard, protective layer formed from all or part of the testa or tegument. Corner (1976) classified seed coats according to the position of this mechanical layer. The seed coat often has important subsidiary functions, usually related to dispersal, and with corresponding specialized structures (Boesewinkel \& Bouman, 1984). The development of the seed margin to be winged and the seed has apical tuft of hairs in Asclepiadaceae for wind dispersal (Sylla \& Albers, 1989). Several authors have long studied the seed morphology and anatomy of some species of family Asclepiadaceae for diagnostic characters of these organs by which the plants can be easily identified both in the entire and powdered forms, (Mahran et al., 1967) (Calotropis procera), Saber et al. (1967) (Pergularia tomentosa); Islam (1991) (Cynanchum acutum); Sarg et al. (1993) (Gomphocarpus sinaicus). Sylla \& Albers (1989) recorded that the simple structure of the seed margin of Vincetoxicum and Cynanchum is 
in contrary to that of the wing like margins of Asclepias and various stapeliads. But both are of different anatomy, and therefore of high taxonomic interest. Heneidak (1995 \& 2001) studied the seed morphology of some species of family Asclepiadaceae in Egypt, and found that the variations were significant.

The present study aims to describe in detail the seed exomorphic characters and seed coat anatomy of ten species of tribe Asclepiadeae (Asclepiadoideae-Apocynaceae) in Egypt to assess the usefulness of the seed characters for taxonomic purposes.

\section{Materials and Methods}

Mature seeds of the species used in this study were taken from field collections and herbarium specimens (Table 1), and the herbarium specimens were kept in the Department of Biology \& Geology, Faculty of Education in Suez, Suez Canal University. The external aspects of 10 seeds for each species were investigated by the aid of stereomicroscope. For SEM studies, a minimum of 2 seeds per species was examined. Seeds were mounted onto stubs, coated with silver using a sputter coating unit, and scanned with a Jeol-JSM-T20 SEM at $20 \mathrm{KV}$ at central services lab., National Research Centre (Dokki, Cairo).

For seed coat anatomy, mature seeds were softened overnight by immersing in $10 \%$ glycerine and $70 \%$ ethanol $(1: 1 \mathrm{~V} / \mathrm{V})$; then hand sectioned at 15-20 $\mu \mathrm{m}$ thickness. The sections were double stained in safranin-light green combination (Willey, 1971). These sections were photographed using a Zeiss photomicroscope at Agricultural Botany Department, Faculty of Agriculture, Suez Canal University. Unstained sections were investigated for the natural pigments they contain. Where the same SEM and anatomical characters are shared by two species only one photograph is presented for either one. 
Table 1. Localities and classification of the studied species of tribe Ascalepiadeae according to Liede (1997), and Endress \& Bruyns (2000). Except for Pergularia daemia and Pentatropis nivalis, all specimens were collected by the authors.

\begin{tabular}{|c|c|c|}
\hline Subtribe & Taxa & Localities \\
\hline \multirow[t]{5}{*}{ Asclepiadinae } & Asclepias fruticosa L. & $\begin{array}{l}\text { Fields between Zifta and } \\
\text { Mît Ghamer, 10.9.1997. }\end{array}$ \\
\hline & $\begin{array}{lll}\text { Asclepias sinaica } & \text { (Boiss.) } \\
\text { Muschl. } & & \\
\end{array}$ & $\begin{array}{ll}\text { Sant } & \text { Catherine, } \\
\text { 15.4.1997. } & \\
\end{array}$ \\
\hline & $\begin{array}{l}\text { Calotropis procera (Aiton) } \\
\text { W. T. Aiton }\end{array}$ & $\begin{array}{l}\text { Suez Canal } \begin{array}{r}\text { univ. } \\
\text { building, } \\
\text { Is.10.2004. }\end{array} \\
\end{array}$ \\
\hline & $\begin{array}{l}\text { Pergularia daemia (Forssk.) } \\
\text { Chiov. }\end{array}$ & $\begin{array}{l}\text { Gebel Elba, top of wadi } \\
\text { Acow, } \\
25.10 .1997, \text { Morsy et al. }\end{array}$ \\
\hline & Pergularia tomentosa $\mathrm{L}$. & $\begin{array}{ll}\text { Ismailia-Fayed } & \text { desert } \\
\text { road, 6.12.2004. } & \end{array}$ \\
\hline Astephaninae & $\begin{array}{l}\text { Pentatropis nivalis (J. F. } \\
\text { Gmel.) } \\
\text { D. V. Field \& J. R. I. Wood }\end{array}$ & $\begin{array}{l}\text { Gebel Elba, } 17 \mathrm{Km} \text { south } \\
\text { Abu Ramad, 30.5.1995, } \\
\text { Morsy et al. }\end{array}$ \\
\hline \multirow[t]{2}{*}{ Glossonematinae } & $\begin{array}{l}\text { Glossonema boveanum } \\
\text { (Decne.) Decne. }\end{array}$ & $\begin{array}{l}\text { Sharm El-Sheikh, Nabq } \\
\text { protectorate, 9.4.1997. }\end{array}$ \\
\hline & $\begin{array}{l}\text { Solenostemma } \\
\text { (Delile) Hayne }\end{array}$ & 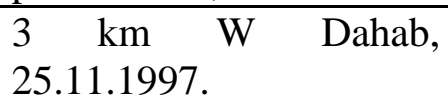 \\
\hline \multirow[t]{2}{*}{ Metastelmatinae } & Cynanchum acutum $\mathrm{L}$. & Suez, Shalufa, 18.9.2004. \\
\hline & $\begin{array}{l}\text { Oxystelma esculentum (L. f.) } \\
\text { R. Br. }\end{array}$ & Suez, Shalufa, 18.9.2004. \\
\hline
\end{tabular}

\section{Observations and Discussion}

\section{Exomorphic seed characters (Table 2, Fig. 1)}

The shape of seed was ovate in two Asclepias species, Calotropis procera, Glossonema boveanum, two Pergularia species and Solenostemma arghel, narrowly ovate in Cynanchum acutum, broadly ovate in Oxystelma esculentum, and ovate-flattened in Pentatropis nivalis. 
The seed colour dark brown in two Asclepias species, Calotropis procera and two Pergularia species, pale brown in Cynanchum acutum, Oxystelma esculentum and Pentatropis nivalis, brown in Glossonema boveanum and Solenostemma arghel.

The seed texture glabrous with numerous creases in two Asclepias species, thinly tomentose in Calotropis procera and Pergularia tomentosa, smooth glabrescent in Cynanchum acutum, Glossonema boveanum and Oxystelma esculentum, minutely irregularly crenate in Pentatropis nivalis, velvety pubescent in Pergularia daemia, and minutely tuberculated in Solenostemma arghel. Seed upper surface was plano-convex in all studied species except the two Asclepias species and Solenostemma arghel where it was concave verrucose face. While seed lower part was plano-convex in all studied species except in two Asclepias species and Solenostemma arghel where it was convex. However, the highest values for average seed size $(8 \mathrm{x}$ $6 \mathrm{~mm}$ ) were recorded in Pergularia tomentosa; and the lowest ones in Oxystelma esculentum ( $3 \times 2 \mathrm{~mm})$.

The seeds have narrowly wing-like margins, which are usually pale in colour and thinner than the seed. These wing-like margins are minute in the two Asclepias species and Solenostemma arghel, narrowly margined as a wing in other species. Hilum is slit-like, apical, leveled, truncate, smooth and pale to dark brown in colour (Figs. $1 \mathrm{k} \& 1$ ) at the narrow end of the seed in all studied taxa under the tuft of silky unicellular hairs (coma) (Fig. $1 \mathrm{~m})$. The highest values for average coma length $(4 \mathrm{~cm})$ were found in Calotropis procera; and the lowest ones were found in Glossonema boveanum $(1.5 \mathrm{~cm})$.

The results obtained from the seed exomorphic characters show that the shape, size, texture and surface are of considerable taxonomic use at generic level. While, the seed colour can be of little use as a taxonomic character because of two or three species have the same colour. Similar conclusions have also been given by Hamed \& Mourad (1994) (Convolvulaceae); AlNowaihi \& Mourad (1999) (Solanaceae). These results are in agreement with those obtained by Mahran et al., 1967 (Calotropis procera), Saber et al. (1967) (Pergularia tomentosa); Islam (1991) (Cynanchum acutum); Sarg et al. (1993) (Gomphocarpus sinaicus). 


\section{Scan Spermoderm Characters (SEM)}

A- Pattern and shape of the epidermal cells (Table 3, Fig. 2)

The seed coat pattern with few mounds and papillae inbetween is characteristic for two Asclepias species, papillae covered by slightly rough hairs in Calotropis procera, papillae in Cynanchum acutum, reticulate in both Glossonema boveanum and Oxystelma esculentum, dense mounds and papillae inbetween in both Pentatropis nivalis and Solenostemma arghel, and papillae covered by dense tuberculated hairs in the two Pergularia species.

The epidermal cells are randomly arranged, 4-6 gonal, and isodiametric in all seeds examined except Glossonema boveanum, Oxystelma esculentum and Solenostemma arghel where they are elongated, and circular-ovate in two Asclepias species.

\section{B- Outer periclinal cell walls}

These are convex in Solenostemma arghel, convex with distinctly protuberance in its central portion in Calotropis procera, convex with variously oblique stalked protuberance in its central portion in two Asclepias species, convex with acute central portion in Cynanchum acutm, slightly convex with distinctly small protuberance in its central portion in Pentatropis nivalis and two Pergularia species, and concave in Glossonema boveanum and Oxystelma esculentum. However, the surface of the outer periclinal cell walls is smooth in two Pergularia species and Solenostemma arghel, tuberculated in Calotropis procera, Cynanchum acutum and Pentatropis nivalis, coarsely tuberculated in Oxystelma esculentum, provided with fine folds in two Asclepias species and Cynanchum acutum, provided with clear striations and reticulate inbetween in Glossonema boveanum.

\section{C- Anticlinal cell wall boundaries}

These boundaries are well developed and indicated by channels in all seeds examined except Cynanchum acutum, Glossonema boveanum and Oxystelma esculentum. These channels are smooth and distinctly deep in two Asclepias species, shallow in Calotropis procera, Pentatropis nivalis and two Pergularia species, or very shallow in Solenostemma arghel. Furthermore, the boundaries are also smooth but slightly raised in Cynanchum acutum, or thick and distinctly raised in Glossonema boveanum and Oxystelma esculentum. 
The SEM micrographs show that the testa sculpture in the studied ten species varied much in its form and appearance. The above mentioned observations show that the epidermal cells differ in shape, their outer periclinal cell walls and their anticlinal walls, and this could be diagnostic parameters at the generic level. The same parameters were likewise considered in Convolvulaceae (Hamed \& Mourad, 1994), in Solanaceae (Al-Nowaihi \& Mourad, 1999); Shaheen, 2002).

Table 2. Seed morphological characters of the studied species of the Asclepiadeae in Egypt

\begin{tabular}{|c|c|c|c|c|c|c|c|c|}
\hline $\begin{array}{l}\text { Characters } \\
\text { Species }\end{array}$ & Shape & Colour & $\begin{array}{l}\text { Average } \\
\text { size } \\
(\mathbf{m m})\end{array}$ & Texture & $\begin{array}{l}\text { Upper } \\
\text { surface }\end{array}$ & $\begin{array}{l}\text { Lower } \\
\text { surface }\end{array}$ & $\begin{array}{l}\text { Seed } \\
\text { wing }\end{array}$ & $\begin{array}{l}\text { Average } \\
\text { coma } \\
\text { Length } \\
\text { (cm) }\end{array}$ \\
\hline $\begin{array}{l}\text { Asclepias } \\
\text { fruticosa }\end{array}$ & Ovate & $\begin{array}{l}\text { Dark } \\
\text { brown }\end{array}$ & $4 \times 2$ & $\begin{array}{l}\text { Glabrous } \\
\text { with } \\
\text { numerous } \\
\text { creases }\end{array}$ & $\begin{array}{l}\text { Concave } \\
\text { face, } \\
\text { verrucose }\end{array}$ & $\begin{array}{l}\text { Strongly } \\
\text { convex }\end{array}$ & Minute & 2.5 \\
\hline $\begin{array}{l}\text { Asclepias } \\
\text { sinaica }\end{array}$ & Ovate & $\begin{array}{l}\text { Dark } \\
\text { brown }\end{array}$ & $5 \times 3$ & $\begin{array}{l}\text { Glabrous } \\
\text { with } \\
\text { numerous } \\
\text { creases }\end{array}$ & $\begin{array}{l}\text { Concave } \\
\text { face, } \\
\text { verrucose }\end{array}$ & $\begin{array}{l}\text { Strongly } \\
\text { convex }\end{array}$ & Minute & 2.5 \\
\hline $\begin{array}{l}\text { Calotropis } \\
\text { procera }\end{array}$ & Ovate & $\begin{array}{l}\text { Dark } \\
\text { brown }\end{array}$ & $7 \times 5$ & $\begin{array}{l}\text { Thinly } \\
\text { tomentose }\end{array}$ & $\begin{array}{l}\text { Plano- } \\
\text { convex }\end{array}$ & $\begin{array}{l}\text { Plano- } \\
\text { convex }\end{array}$ & $\begin{array}{l}\text { Narrowly } \\
\text { margined }\end{array}$ & 4 \\
\hline $\begin{array}{l}\text { Cynanchum } \\
\text { acutum }\end{array}$ & $\begin{array}{l}\text { Narrowly } \\
\text { ovate }\end{array}$ & $\begin{array}{l}\text { Pale } \\
\text { brown }\end{array}$ & $8 \times 4$ & $\begin{array}{l}\text { Smooth, } \\
\text { glabrescent }\end{array}$ & $\begin{array}{l}\text { Plano- } \\
\text { convex }\end{array}$ & $\begin{array}{l}\text { Plano- } \\
\text { convex }\end{array}$ & $\begin{array}{l}\text { Narrowly } \\
\text { margined }\end{array}$ & 3 \\
\hline $\begin{array}{l}\text { Glossonema } \\
\text { boveanum }\end{array}$ & Ovate & Brown & $6 \times 5$ & $\begin{array}{l}\text { Smooth, } \\
\text { glabrescent }\end{array}$ & $\begin{array}{l}\text { Plano- } \\
\text { convex }\end{array}$ & $\begin{array}{l}\text { Plano- } \\
\text { convex }\end{array}$ & $\begin{array}{l}\text { Narrowly } \\
\text { margined }\end{array}$ & 1.5 \\
\hline $\begin{array}{l}\text { Oxystelma } \\
\text { esculentum }\end{array}$ & $\begin{array}{l}\text { Broadly } \\
\text { ovate }\end{array}$ & $\begin{array}{l}\text { Pale } \\
\text { brown }\end{array}$ & $3 \times 2$ & $\begin{array}{l}\text { Smooth, } \\
\text { glabrescent }\end{array}$ & $\begin{array}{l}\text { Plano- } \\
\text { convex }\end{array}$ & $\begin{array}{l}\text { Plano- } \\
\text { convex }\end{array}$ & $\begin{array}{l}\text { Narrowly } \\
\text { margined }\end{array}$ & 1.7 \\
\hline $\begin{array}{l}\text { Pentatropis } \\
\text { nivalis }\end{array}$ & $\begin{array}{l}\text { Ovate- } \\
\text { flattened }\end{array}$ & $\begin{array}{l}\text { Pale } \\
\text { brown }\end{array}$ & $5 \times 3$ & $\begin{array}{l}\text { Minutely } \\
\text { irregularly } \\
\text { crenate }\end{array}$ & $\begin{array}{l}\text { Plano- } \\
\text { convex }\end{array}$ & $\begin{array}{l}\text { Plano- } \\
\text { convex }\end{array}$ & $\begin{array}{l}\text { Narrowly } \\
\text { margined }\end{array}$ & 2 \\
\hline $\begin{array}{l}\text { Pergularia } \\
\text { daemia }\end{array}$ & Ovate & $\begin{array}{l}\text { Dark } \\
\text { brown }\end{array}$ & $8 \times 4$ & $\begin{array}{l}\text { Velvety } \\
\text { pubescent }\end{array}$ & $\begin{array}{l}\text { Plano- } \\
\text { convex }\end{array}$ & $\begin{array}{l}\text { Plano- } \\
\text { convex }\end{array}$ & $\begin{array}{l}\text { Narrowly } \\
\text { margined }\end{array}$ & 3 \\
\hline $\begin{array}{l}\text { Pergularia } \\
\text { tomentosa }\end{array}$ & Ovate & $\begin{array}{l}\text { Dark } \\
\text { brown }\end{array}$ & $8 \times 6$ & $\begin{array}{l}\text { Thinly } \\
\text { tomentose }\end{array}$ & $\begin{array}{l}\text { Plano- } \\
\text { convex }\end{array}$ & $\begin{array}{l}\text { Plano- } \\
\text { convex }\end{array}$ & $\begin{array}{l}\text { Narrowly } \\
\text { margined }\end{array}$ & 3 \\
\hline $\begin{array}{l}\text { Solenostemma } \\
\text { arghel }\end{array}$ & Ovate & Brown & $6 \times 3$ & $\begin{array}{l}\text { Minutely } \\
\text { tuberculate }\end{array}$ & $\begin{array}{l}\text { Concave } \\
\text { face, } \\
\text { verrucose }\end{array}$ & $\begin{array}{l}\text { Strongly } \\
\text { convex }\end{array}$ & Minute & 2 \\
\hline
\end{tabular}




\section{A- Anatomy of seed coat}

The seed coat is formed of four zones; an outer epidermis followed by subepidermis representing the outer integument; while the inner integument is formed of sclerenchyma layer followed by the pigment layer (a collapsed layer of sclerenchyma cells) (Table 4 and Fig. 3).

\section{a- Epidermis}

The shape of epidermal cells shows a great variation, it is ovate, papillose in two Asclepias species and Oxystelma esculentum, ovate in Calotropis procera, polygonal in Cynanchum acutum, ovate, papillose and radially elongated in Glossonema boveanum, square-sub rectangular in Pentatropis nivalis and two Pergularia species, and rectangular, radially elongated in Solenostemma arghel. They are thin in Calotropis procera, Glossonema boveanum, Oxystelma esculentum and Pentatropis nivalis, and thick in the other taxa. The epidermal cells show different pigment colour, brown in two Asclepias species and Cynanchum acutum, pale brown in Calotropis procera, Pentatropis nivalis and Solenostemma arghel, purplish brown in Glossonema boveanum, reddish brown in Oxystelma esculentum, and dark brown in two Pergularia species. They extend outwards into papillae in two Asclepias species, Cynanchum acutum, Glossonema boveanum, Oxystelma esculentum, or unicellulear hairs in Calotropis procera and two Pergularia species. Furthermore, the presence of mounds on the concave upper side of the seed coat is recorded only in two Asclepias species and Solenostemma arghel, with large, tubular, lignified, pitted cells in two Asclepias species, and small, rectangular, radially elongated in Solenostemma arghel.

\section{b- Subepidermis}

The number of layers of the subepidermis is two to many layers in Solenostemma arghel, 2-3 layers in two Pergularia species, and one layer in the other taxa. The shape of its cells is tangentially elongated in Calotropis procera, two Pergularia species and Solenostemma arghel, and somewhat tangentially elongated in the six remaining taxa. The subepidermal cells are thick only in Cynanchum acutum and Oxystelma esculentum, and thin in other taxa. Their pigment colour is brown in Solenostemma arghel, absent in Glossonema boveanum and Pentatropis nivalis, and pale brown in the seven remaining taxa. Moreover, the cells of the subepidermis contain solitary crystals in all the studied taxa. 


\section{c- Collapse layer (sclerenchyma layer)}

This layer is absent in Glossonema boveanum and Pentatropis nivalis, and present in the eight remaining taxa. It consists of five layers in two Asclepias species, and one in other taxa. The colour of collapse layer is dark brown in Calotropis procera, pale brown in two Asclepias species, Cynanchum acutum.
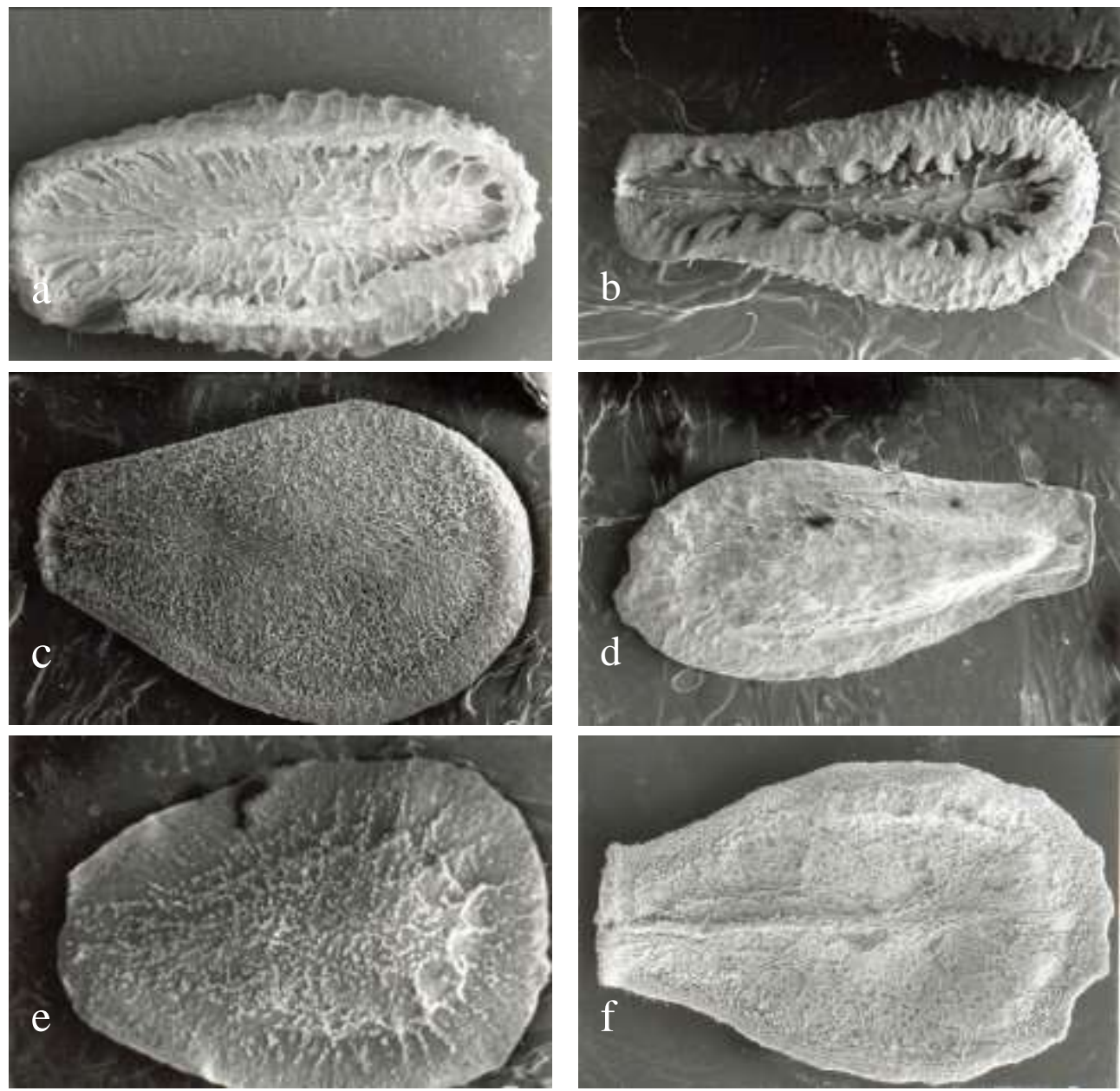

Fig. 1. SEM micrographs of the upper surface of the seeds of the studied species.
a. Asclepias fruticosa
(x 21)
b. Asclepias sinaica
(x 22)
c. Calotropis procera
(x 16)
d. Cynanchum acutum
$(\mathrm{x} 15)$
e. Glossonema boveanum (x 22) f. Oxystelma esculentum (x 50) 

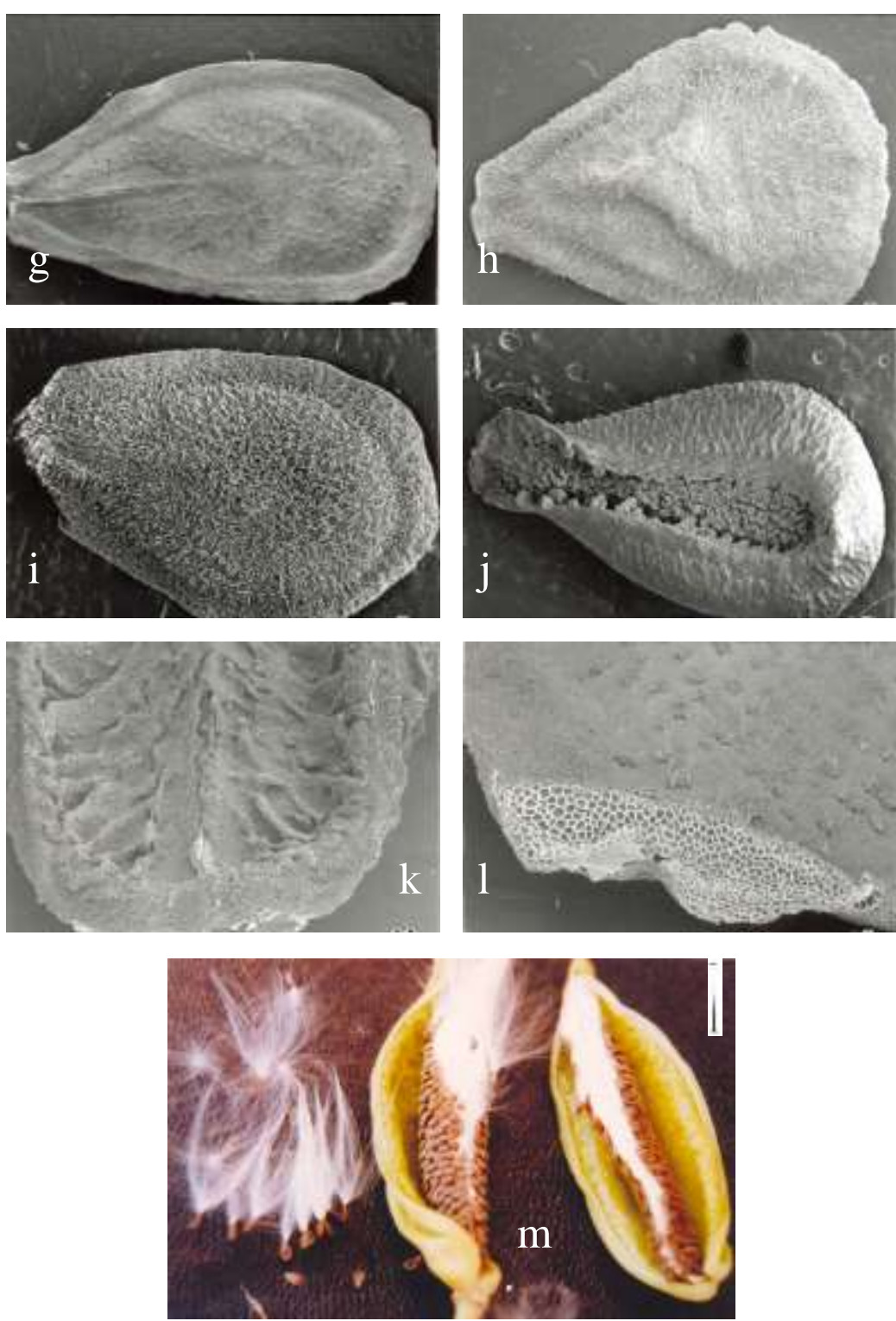

Fig. 1. cont.

g. Pentatropis nivalis (x 20), h. Pergularia daemia (x 19), i. Pergularia tomentosa (x 17), j. Solenostemma arghel (x 10), k. Asclepias fruticosa (hilum region, x 51), 1. Pentatropis nivalis (hilum region, x 100), m. Oxystelma esculentum [seeds with a tuft of hairs (coma), scale bar $=1 \mathrm{~cm}$ ] 

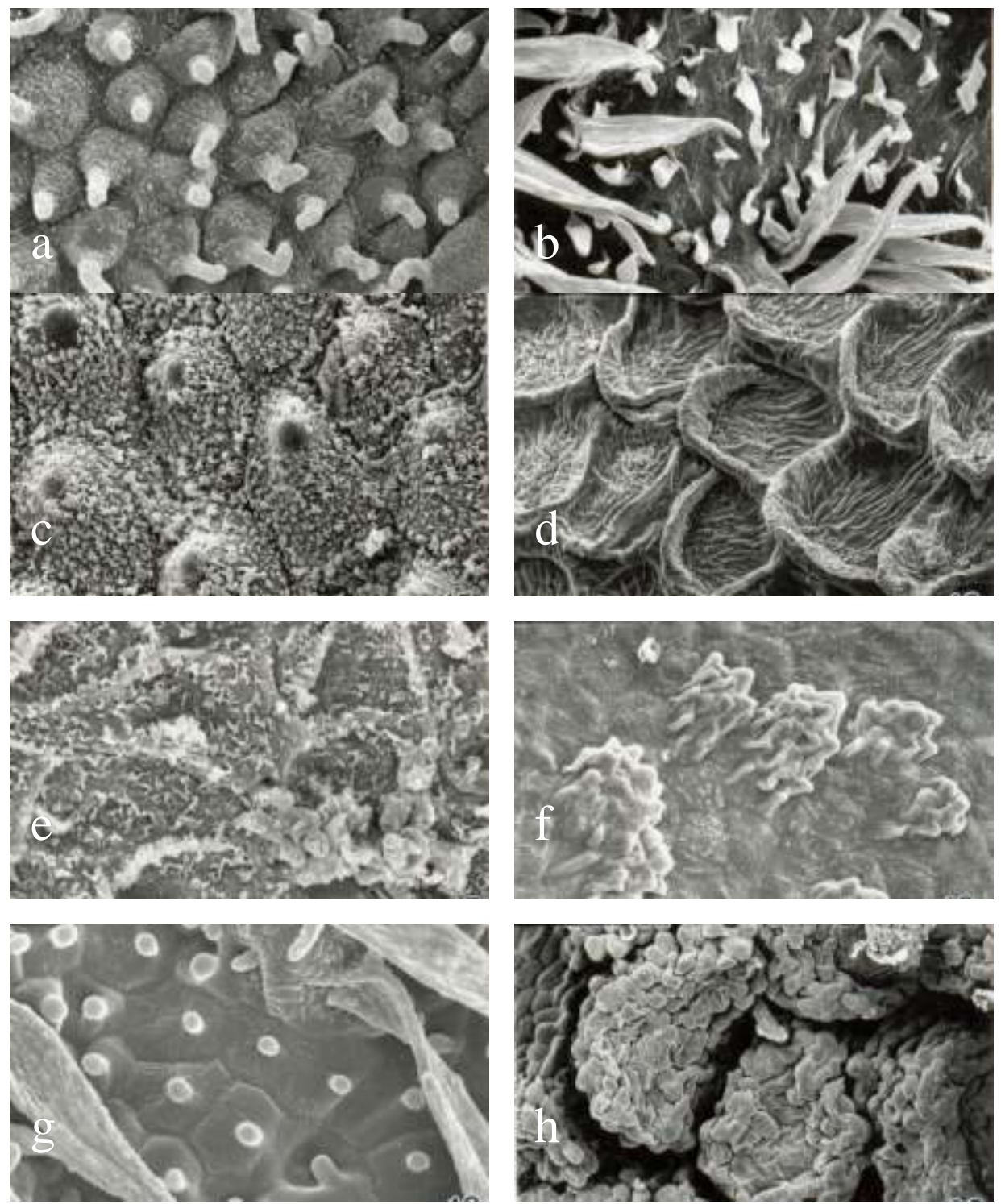

Fig. 2: SEM micrographs of the seed surface showing spermoderm pattern among the studied taxa.
a. Asclepias sinaica
(x 1026) b. Calotropis procera
(x 622)
c. Cynanchum acutum (x 1023) d. Glossonema boveanum (x 1022)
e. Oxystelma esculentum (x 893) f. Pentatropis nivalis
(x 477)
g. Pergularia daemia
(x 883) h. Solenostemma arghel
(x 386) 


\section{d- Parenchyma mucilage cells:}

It represents the innermost seed coat layer with thin-walled, hyaline cells, and consists of four layers in two Asclepias species, Cynanchum acutum and Oxystelma esculentum, five layers in Calotropis procera, and many layers in the other taxa. These parenchyma cells are large in two Asclepias species Cynanchum acutum, and small in the other taxa. Mucilage is either clearly detectable in two Asclepias species, Calotropis procera and Cynanchum acutum, or slightly detectable in the other six taxa.

\section{B- Anatomy of seed wing: (Table 5 and Fig. 4)}

The wing is formed of an epidermis, subepidermis, followed by palisade- like cells (present in few taxa), and collapse layer in the center in most of the studied taxa, or thin-walled parenchyma in the center in few taxa.

\section{a- Epidermis:}

The epidermal cells are more radially elongated than the seed coat. They consist of large tubular, lignified, pitted cells in two Asclepias species, rectangular, slightly radially elongated in Calotropis procera, polygonal, slightly radially elongated in Cynanchum acutum, ovate, radially elongated in Glossonema boveanum (as in seed coat, square-ovate, papillose, slightly radially elongated in Oxystelma esculentum, square-sub rectangular in Pentatropis nivalis and two Pergularia species, and rectangular, radially elongated in Solenostemma arghel.

\section{b- Subepidermis:}

It is like that of the seed coat. The cells of the subepidermis contain solitary crystals in all the studied taxa.

\section{c- Palisade-like cells:}

The presence of two rows of the palisade-like cells in the seed wing of two Pergularia species (one upper and one lower enclosing the collapse layer between them), these cells show uniformly thick walls.

\section{d- Collapse layer (sclerenchyma layer):}

The outer and inner layers of collapsed cells are extending from the seed coat and meet in the center of the seed wing in two Asclepias species, Cynanchum acutum, Oxystelma esculentum, Pentatropis nivalis, two 
Pergularia species and Solenostemma arghel. The colour of collapse layer is brown in Solenostemma arghel, pale reddish brown in Oxystelma esculentum, and pale brown in the other six taxa.

\section{f- Parenchyma mucilage cells:}

The outer and inner layers of thin-walled, hyaline parenchyma mucilage cells are extending from the seed coat and meet in the center of the seed wing in Calotropis procera Glossonema boveanum, two Pergularia species and Solenostemma arghel.

These results obtained from the seed anatomy (epidermis, subepidermis, collapse layer and parenchyma mucilage cells) provide a good differentiation between the studied taxa, especially at the generic level. A similar conclusion has been given by Hamed \& Mourad (1994) (Convolvulaceae); Al-Nowaihi \& Mourad (1999); Shaheen (2002) (Solanaceae). The presence of palisade-like cells in the seed wing of two Pergularia species is similar to these of Asclepias species (Sylla \& Albers, 1989). These palisade-like cells are absent in the studied two Asclepias species, as well as in the other studied taxa. These taxa are characterized by seed wing with simple structure as he observed in Vincetoxicum and Cynanchum.

\section{Relationships of Taxa}

The observations of the seed exomorphic, scan spermoderm and anatomy presented show that the most useful criteria are shape, colour, texture, the presence or absence of mounds on the upper side, the shape of the epidermal cells, outer periclinal cell walls, anticlinal cell wall boundaries, the number of layers of the subepidermis, the presence or absence and the number of collapse layer, the number of layers and the size of parenchyma mucilage cells, and the presence or absence of palisade-like cells, collapse layers and parenchyma mucilage cells in the seed wing. It has been possible to distinguish between the studied genera, each with a characteristic pattern, on the basis of morphological and anatomical characters. 

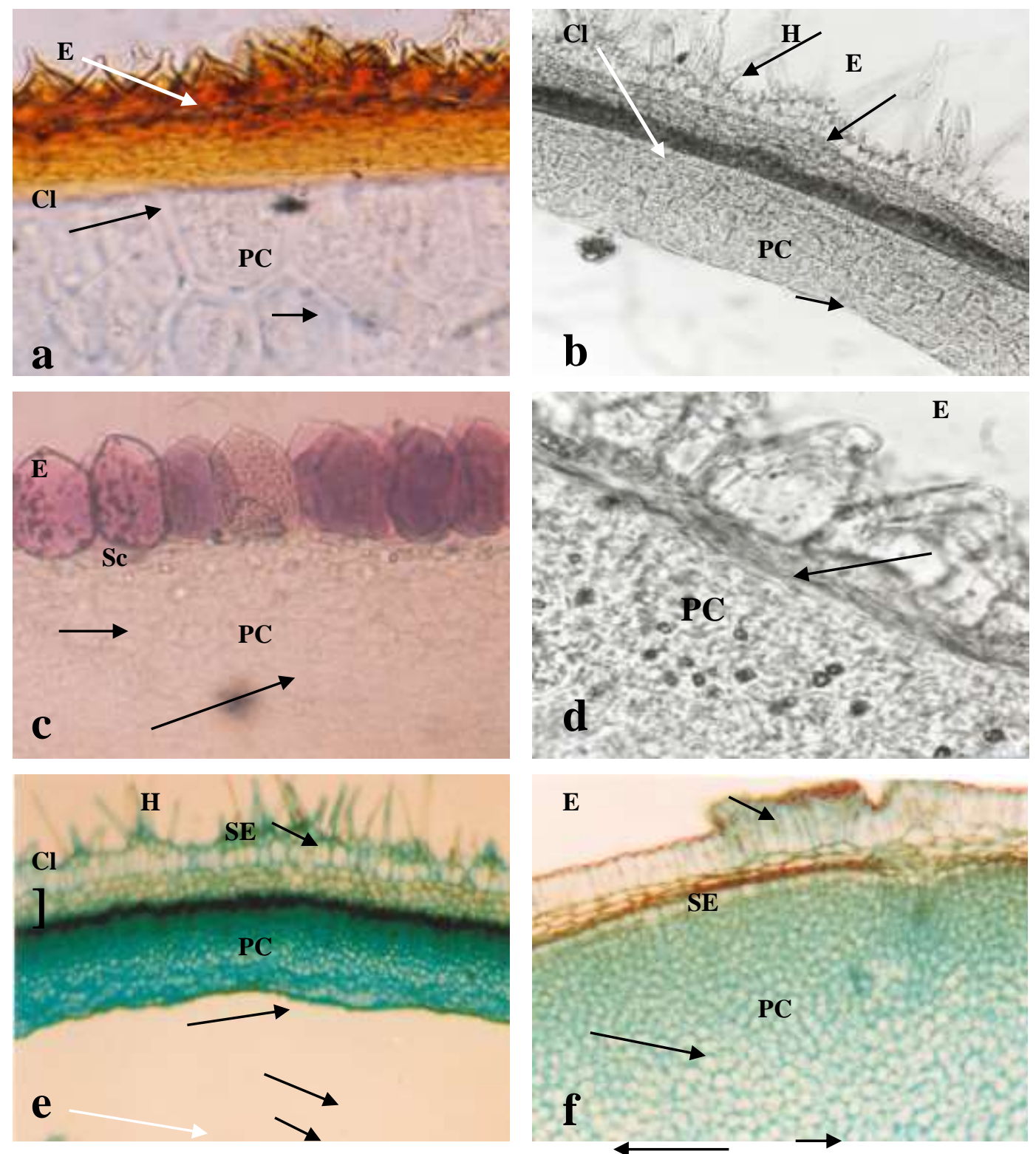

Fig. 3: Seed coat anatomy of the studied species.

a. Asclepias sinaica (x 128)

b. Calotropis procera (x 32)

c. Glossonema boveanum (x 64)

d. Oxystelma esculentum (x 128)

e. Pergularia tomentosa (x 12.8)

f. Solenostemma arghel (x 32)

Collapse layer $(\mathrm{Cl})$, epidermis $(\mathrm{E})$, hairs $(\mathrm{H})$, parenchyma cells $(\mathrm{PC})$, solitary crystals (Sc), subepidermis (SE) 
Table 5. Anatomical characters of seed wing of the studied species of the Asclepiadeae in Egypt. Presence (+), absence (-).

\begin{tabular}{|c|c|c|c|c|c|c|c|}
\hline \multirow{2}{*}{$\begin{array}{l}\text { Characters } \\
\text { Species }\end{array}$} & \multirow{2}{*}{ Epidermis shape } & \multicolumn{2}{|c|}{ Palisade like cells } & \multicolumn{2}{|c|}{ Collapse layer } & \multicolumn{2}{|c|}{$\begin{array}{l}\text { Parenchyma } \\
\text { mucilage cells }\end{array}$} \\
\hline & & $\begin{array}{l}\begin{array}{l}\text { Presence/ } \\
\text { absence }\end{array} \\
\end{array}$ & $\begin{array}{l}\text { No. of } \\
\text { layers }\end{array}$ & $\begin{array}{l}\begin{array}{l}\text { Presence/ } \\
\text { absence }\end{array} \\
\end{array}$ & $\begin{array}{l}\text { Pigment } \\
\text { colour }\end{array}$ & $\begin{array}{l}\text { Presence/ } \\
\text { absence }\end{array}$ & $\begin{array}{l}\text { Size of } \\
\text { cells }\end{array}$ \\
\hline $\begin{array}{l}\text { Asclepias } \\
\text { fruticosa }\end{array}$ & Large tubular & - & - & + & $\begin{array}{l}\text { Pale } \\
\text { brown }\end{array}$ & - & - \\
\hline $\begin{array}{l}\text { Asclepias } \\
\text { sinaica }\end{array}$ & Large tubular & - & - & + & $\begin{array}{l}\text { Pale } \\
\text { brown }\end{array}$ & - & - \\
\hline $\begin{array}{l}\text { Calotropis } \\
\text { procera }\end{array}$ & $\begin{array}{l}\text { Rectangular, } \\
\text { slightly radially } \\
\text { elongated }\end{array}$ & - & - & - & - & + & Small \\
\hline $\begin{array}{l}\text { Cynanchum } \\
\text { acutum }\end{array}$ & $\begin{array}{l}\text { Polygonal, } \\
\text { slightly radially } \\
\text { elongated }\end{array}$ & - & - & + & $\begin{array}{l}\text { Pale } \\
\text { brown }\end{array}$ & - & - \\
\hline $\begin{array}{l}\text { Glossonema } \\
\text { boveanum }\end{array}$ & $\begin{array}{l}\text { Ovate, radially } \\
\text { elongated }\end{array}$ & - & - & - & - & + & Small \\
\hline $\begin{array}{l}\text { Oxystelma } \\
\text { esculentum }\end{array}$ & $\begin{array}{l}\text { Square-ovate, } \\
\text { papillose, slightly } \\
\text { radially elongated }\end{array}$ & - & - & + & $\begin{array}{l}\text { Pale } \\
\text { reddish } \\
\text { brown }\end{array}$ & - & - \\
\hline $\begin{array}{l}\text { Pentatropis } \\
\text { nivalis }\end{array}$ & $\begin{array}{l}\text { Square-sub } \\
\text { rectangular }\end{array}$ & - & - & + & $\begin{array}{c}\text { Pale } \\
\text { brown }\end{array}$ & - & - \\
\hline $\begin{array}{l}\text { Pergularia } \\
\text { daemia }\end{array}$ & $\begin{array}{l}\text { Square-sub } \\
\text { rectangular }\end{array}$ & + & 1 & + & $\begin{array}{l}\text { Pale } \\
\text { brown }\end{array}$ & - & - \\
\hline $\begin{array}{l}\text { Pergularia } \\
\text { tomentosa }\end{array}$ & $\begin{array}{l}\text { Square-sub } \\
\text { rectangular }\end{array}$ & + & 1 & + & $\begin{array}{l}\text { Pale } \\
\text { brown }\end{array}$ & - & - \\
\hline $\begin{array}{l}\text { Solenostemma } \\
\text { arghel }\end{array}$ & $\begin{array}{l}\text { Rectangular, } \\
\text { radially elongated }\end{array}$ & - & - & + & Brown & + & Small \\
\hline
\end{tabular}

The seed exomorphic and scan spermoderm suggest also a close relationship between Calotropis procera and the two Pergularia species belonging to the same subtribe Asclepiadinae. They show ovate, dark brown; thinly tomentose seeds, and anticlinal cell wall boundaries of the epidermal cells with shallow channels. While, this relationship is not supported by the seed coat anatomy, especially the presence of one layer of the palisade-like cells is characteristic for the seed wing of the two Pergularia species.

The seed exomorphic and scan spermoderm suggest also a close relationship between Glossonema boveanum (subtribe Glossonematinae) and Oxystelma esculentum (subtribe Metastelmatinae). They are characterized by smooth seed, reticulate coat pattern, elongated epidermal cells, concave outer periclinal cell walls, and distinctly raised anticlinal cell wall boundaries. This relationship is supported by the seed coat anatomy, 

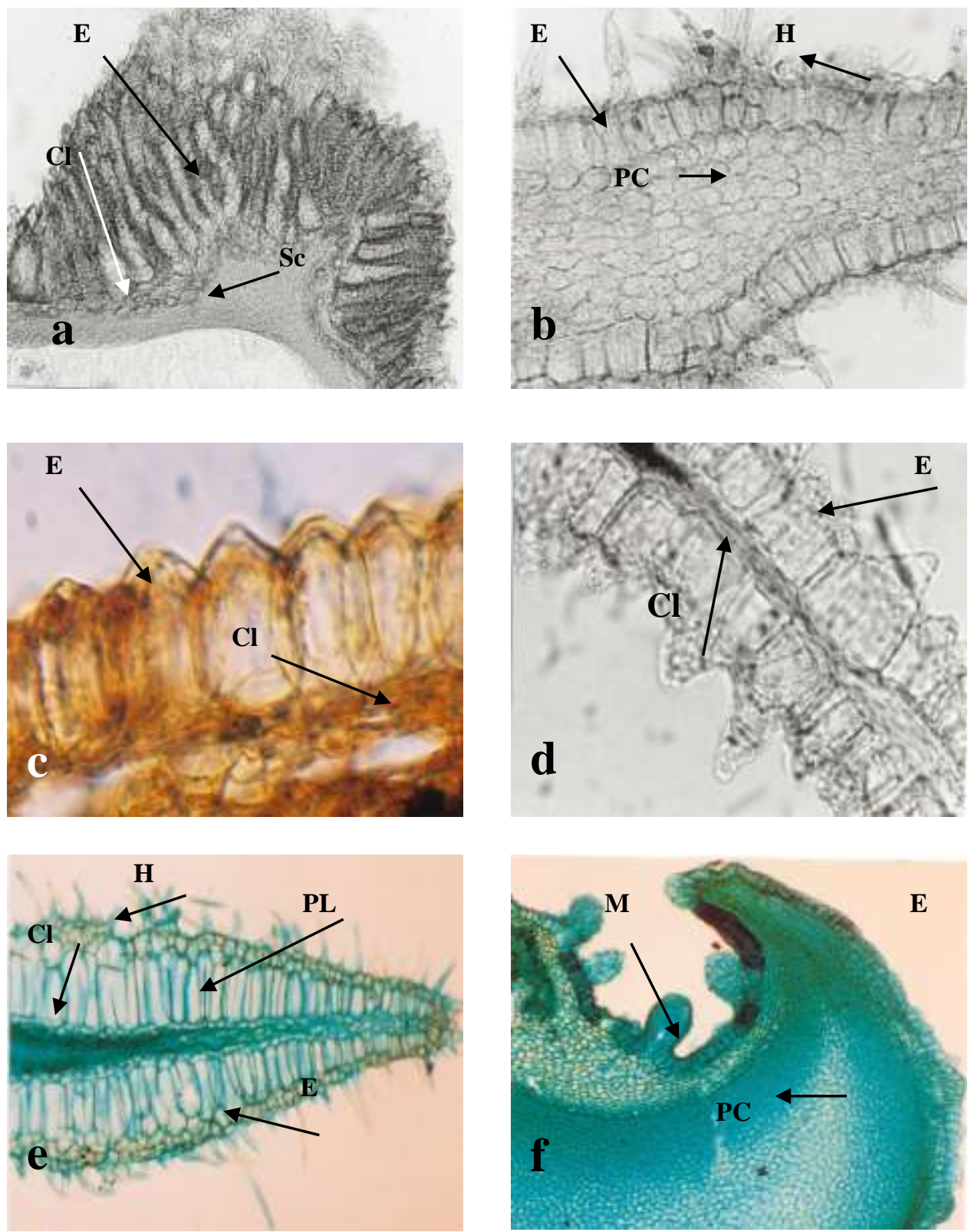

Fig. 4: Seed wing coat anatomy of the studied species.
a. Asclepias sinaica
(x 80)
b. Calotropis procera
(x 32)
c. Cynanchum acutum (x 128)
d. Oxystelma esculentum (x 128)

e. Pergularia tomentosa (x 12.8) f. Solenostemma arghel (x 32)

Collapse layer $(\mathrm{Cl})$, epidermis $(\mathrm{E})$, hairs $(\mathrm{H})$, mounds $(\mathrm{M})$, parenchyma cells $(\mathrm{PC})$, palisade layer (PL), solitary crystals (Sc), subepidermis (SE) 
which shows ovate, papillose epidermal cells, one layer subepidermis, and parenchyma mucilage cells of many layers with small cells.

The seed morphological and anatomical characters show some similarities between Cynanchum acutum (subtribe Metastelmatinae) and Pentatropis nivalis (subtribe Astephaninae). These similarities are narrowly ovate-flattened shape, the presence of papillae in the coat, isodiametric epidermal cells, convex outer periclinal cell walls with tuberculated surface, one layer subepidermis, many layers parenchyma mucilage cells, and the center of the seed wing of collapse layers.

\section{Acknowledgements}

We thank Prof. Dr. Ahmed Mursi Ahmed (Desert Research Center) for providing the herbarium specimens of Gebel Elba, and the members of the Botany Department, Faculty of Agriculture, Suez Canal University, Ismailia, for giving us a share to their departmental facilities.

\section{References}

Al-Nowaihi, A. \& Mourad, M. M. 1999. Morphological and anatomical characters of the spermoderm of certain taxa of the tribe Solaneae (Solanaceae). Taeckholmia 19 (2): 157-181.

Boesewinkel, F. D. \& Bouman, F. 1984. The seed structure. In: B. M. Johri (Ed.), Embryology of Angiosperms. Springer-Verlag, Berlin.

Boulos, L. 1995. Flora of Egypt, Checklist, 283pp. Al Hadara, Pub. Cairo, Egypt.

2000. Flora of Egypt, Vol. 3. pp: 228-229. Al Hadara Publishing, Cairo, Egypt.

Corner, E. J. H. 1976. The Seed of Dicotyledons. Cambridge University Press, Cambridge.

El Hadidi, M. N. \& Fayed, A. A. 1994/1995. Materials for Excursion Flora of Egypt [EFE]. Taeckholmia 15: 117-120.

Endress, M. E. \& Bruyns P. V. 2000. A revised classification of the Apocynaceae s.l. Botanical Review 66: 1-56.

Govil, C. M. 1980. Comparative embryology of Convolvulaceae and Cuscutaceae. Journal of the Indian Botanical Society 59: 28. 
Hamed, K. A. \& Mourad, M. M. (1994). Seed exomorphic and anatomical characters of some species of Convolvulaceae. Egyptian Journal of Botany 34(1): 1-16.

Heneidak, S. 1995. Taxonomic studies on some Egyptian species of the family Asclepiadaceae. M.Sc. Thesis, Fac. Sci. Suez Canal Univ. 291 pp.

2001. Biosystematic studies on the species of subfamilies Asclepiadoideae and Periplocoideae (Family Apocynaceae sensu lato) in Egypt. Ph. D. Thesis, Fac. Sci., Suez Canal Univ. 285 pp.

Heywood, V. H. 1978. Flowering Plants of the World, pp: 263-264. Oxford Univ. Press, Oxford, London and Melbourne.

Islam, W. T. 1991. A pharmacognostical study of Cynanchum acutum growing in Egypt. Thesis, Ph.D., Pharmacognosy Dept., Fac. Pharm. Cairo Univ.

Lawrence, G. H. M. 1978. Taxonomy of Vascular Plants, ed. 5, pp: 673-675. Oxford \& IBH publishing Co. New Delhi.

Liede, S. 1997. Subtribes and genera of the Asclepiadeae (Apocynaceae, Asclepiadoideae) - a synopsis. Taxon 46: 233-247.

Mabberley, D. J. 1997. The Plant-Book, pp: 59-60. Cambridge University Press, Cambridge.

Mahran, G. H., Saber, A. H. \& Khairy, N. H. 1967a. A phytochemical investigation of Pergularia tomentosa growing wild in Egypt. J. Pharm. Sci., U.A.R. 8: 101-125.

Mahran, G. H., Saber, A. H. \& Rizkallah, M. M. 1967b. Calotropis procera. Part 4. The fruit, its macro- and micromorphology. J. Pharm. Sci., U. A. R. 8: 81-100.

Rudall, P. 2000. Anatomy of Flowering Plants (An introduction to structure and development), ed. 2: p. 75. Cambridge University Press.

Saber, A. H., Mahran, G. H. \& Khairy, N. H. 1967. Pergularia tomentosa. Part III. The fruit, its macro- and micromorphology. J. Pharm. Sci., U.A.R. 8: $159-170$.

Sampathkumar, R. \& Ayyangar, K. R. 1978. Seed morpho-anatomy of Convolvulaceae. Journal of the Indian Botanical Society 57: 28.

Sarg, T., El-Domiaty, M., Abd El-Aziz E. \& Abou-Hashem M. 1993. Macro- and Micromorphology of the flowers and fruits of Gomphocarpus sinaicus Boiss. Family Asclepiadaceae Growing in Egypt. Egypt. J. Pharm. Sci. 34 (4-6): 477-504. 
Shaheen, A. M. 2002. Taxonomic implications of seed coat characters in native and naturalized species of Solanum L. Taeckholmia 22(2): 131140.

Singh, G. B., Misri, A. \& Kachroo, P. 1972. Achene morphology as an aid to taxnonomy of Indian plants. I. Compositae Liguliferae. Journal of the Indian Botanical Society 51: 235-247.

Sylla, Th. \& Albers, F. 1989. Samenentwicklung und Samenmorphologie krautiger und sukkulenter Asclepiadaceae. Bot. Jahrb. Syst. 110: 479492.

Täckholm, V. 1956. Students' Flora of Egypt. pp: 179-185. Anglo-Egyptian Bookshop, Cairo.

Täckholm, V. 1974. Students' Flora of Egypt, ed. 2, pp: 416-418. Cairo University.

Willey, R. L. 1971. Microtechnique. A laboratory Guide. Macmillan Publishing Co., Inc., N. Y., 99pp. 